\title{
Twombly's Roses
}

Thomas Schestag

Brown University

Following a studied detour through C. G. Jung, T. S. Eliot, D. H. Lawrence, and particularly R. M. Rilke, this essay tracks the lineage along which Cy Twombly, like a child, is "drawn to paint."

Thomas Schestag is Professor or German at Brown University. His most recent publications include Realabsenz, Schatten: Flauberts Erziehung: zur Éducation sentimentale; mit einem Anhang: sensus tacitus (Berlin: August Verlag, 2011) and Lesen - Sprechen - Schreiben (Kritzeln) (Berlin: Matthes \& Seitz, 2014).

What draws a child to paint? This question, which reaches for the origin of painting in the pose of a drawing child, is preceded and haunted by an answer, itself haunted by a child. In one of his rare interviews, recorded by David Sylvester in London in June 2000, Cy Twombly draws the art historian's attention to the nature of paint: "It's a sort of infantile thing, painting. Paint in a sense is a certain infantile thing." Both sentences are like versions or revisions of a third, a paradigm or theme, which they remain unable to verbalize. They form a stammering, scattered statement. A palpitation. A palpation. Both sentences are about a certain pain involved in saying what paint is all about. Paint is a sort of, paint in a sense, paint is a certain - that is, highly uncertain - infantile thing. An infantile thing, first of all, is not a child's thing. It is as if it was: is mimicking and imitating. But if paint, according to Twombly's palpating words, is a sort of infantile thing, which in its turn is as if it was a child's thing, then paint is mimicking the mimicking gesture of infantile things. Paint is much closer to a child's thing than all things infantile. (In an interview with Hayden Herrera in August 1994, Twombly says of his line that it is "childlike but not childish," adding that childlikeness is "very difficult to fake: to get that quality you need to project yourself into the child's line. It has to be felt.") The task of painting is to draw like a child drawn to drawing and, in so doing, to overcoming all likeness. The question was: What draws a child to paint? But the answer is not simply a given. 
For it tends towards something like: What draws to paint is a child drawn to paint. The answer in a sense refers back to the question.

But within the inner fold of this reference Twombly inserts the word infantile. Infantile, the word, not only refers to a childlike behavior, but to the child itself: to the child's relation to spoken language. Children, according to a powerful tradition, predating Roman antiquity, are speechless: infans. They do not (yet) speak, but imitate or mimic a human being's linguistic gestures. Children imitate the gestures of adults, who by definition (an Aristotelian definition) are human beings only because of their grasp of language: logon echon. A child's appearance, as comforting and promising as it might appear, since it appears as the perpetration of the human species, is always a danger for the terminological determination of human beings and their grasp of language. A child's appearance always brings to mind at least two images: the task of drawing the child away from its childlike behavior and towards language; and that of the child we once were, being drawn away from childishness and invited to speak, inside one or another language, and to respond to spoken words. One might call both images, which in a sense overlap, archeological and teleological. The superimposition of both drawings in a sense situates the drawing child, which is driven by neither teleological nor archeological needs. Paint in a sense doesn't speak: it is a sort of infantile thing. Whoever paints is drawn to paint by a child that does not yet speak. Painting in silence. On the one hand a child imitates or mimics the words and gestures of human beings, on the other hand it does something else. There is in a child who imitates on the one hand, - but not necessarily on the other hand -, something inimitable at work. One may call it inmitation. This privative in-, like the in- of infans, suggests an inclination, that of being drawn to paint. (But the line it draws is not straightforward.)

In another interview, recorded seven years later by Nicholas Serota, during two conversations in Rome, in September and December 2007, Twombly explicitly links painting to a certain use of language, namely written language, which he calls literature and poetry: "I never really separated painting and literature because l've always used reference.... I like poets because I can find a 
condensed phrase.... My greatest one to use was Rilke, because of his narrative, he's talking about the essence of something. I always look for the phrase.... Lines have a great effect on paintings. They give great emphasis." If paint in a sense is a certain infantile thing, and if Twombly never really separated painting and literature, then what attracts him in literature - and poetry a fortiori - is a certain infantile thing as well. Painting and literature refer to each other much less than they refer to some other, a third party: the painting and lettering, littering child. Literature, no less than painting, relates to a child's relation to language. Poetry, no less than infans, is the name for a certain borderline experience with language. Poetry, as the Greek verb poiein indicates, is doing or making - something with language, and in so doing, does something to language. Poetry does something speechless or infantile to language, here considered as a tool and medium, or instrument of communication and, as such, as the quintessence of being human. Poetry undoes the hold - echein - of language; it loosens the grip. When painting, Twombly likes to use poetry, which already does something - childlike - to language by interrupting its everyday use and doing something useless to the medium par excellence of use. When painting, Twombly likes to use the uselessness of poetry. The greatest of all poets Twombly ever used was Rilke. And he explains why: "because of his narrative, he's talking about the essence of something. I always look for the phrase." And: "Lines have a great effect on paintings. They give great emphasis." What Twombly is always looking for in poetry, is a condensed phrase. A phrase that narrates (but only as if it were narrating) the essence of the phrase. The quintessence of phrasis - or speech - is neither speech nor speechlessness, but the line's or verse's effect on painting (or drawing) - the verse, or line. The phrase or line affecting paint gives great emphasis. But phasis in Greek, is, as you know, a condensation of two homonymous nouns: on the one hand phasis derives from phaino, meaning the apparition of something; while on the other hand phasis, deriving from pheimi, refers to a paralinguistic utterance or expression, that is less words than a trembling voice. In phasis, and a fortiori in emphasis, paint and speech overlap in a sense: the gesture of phatic speech just 
as the gesture of drawing emphatically tend towards a phrase or line which is not withdrawn from its phatic or emphatic coming, but draws attention to what everyday speech and everyday paint try to dim or overcome in order to communicate intended meaningful phrases or represent intended figures, including figures of speech. In phatic speech - and no phrase comes into being without phasis (at the brink of aphasia) -, as well as in emphatic drawing - and no line comes into being without a trace of remembrance of what drew one to drawing (at the brink of oblivion) -, something rises, but without having been raised (like a child). Something rose - like a child.

The greatest poet Twombly ever used, as he says, was Rilke; and among Rilke's poems Twombly uses those about roses. These poems condense the rose. The (phatic or emphatic) essence of the phrase - or prose - is rose. Paint is drawn, in a sense, towards this - rose.

Keeping in mind this rose - in its verbal and in its nominal shape, but probably neither as verb nor as noun -, and before turning to Twombly's roses, I'd like to draw your attention to two similar passages, referring to a third, in both of Twombly's interviews, with David Sylvester and Nicholas Serota, from which I have been quoting. In both cases Twombly first refers to a series of paintings from the summer of 1961, entitled Ferragosto, and then refers to what he calls that little story. Here is the little story according to the London-recording of June 2000: "There's a lot of tactile paint in those... you know which ones? Some of them got very heavy, like the last of the series called Ferragosto. It really gets heavy because paint is a certain thing. I don't have a dislike for it, but those paintings, for instance, were done in August in terrific heat in Rome. All my things, every one of them, show a certain agitation. And I have a certain kind of knowledge of things. And there are certain elements that I use. This double image like the brown paint, it's verbal. There's a Jungian example of a small child. It's based on the use of words, how you affect the child. / The child is in the bathroom and the father gets very anxious. So he goes to the door and says 'What are you making?' and she says 'Four horses and a carriage.' She was making a sculpture. Because children have that. It's a sort of infantile thing. I 
mean in the handling." The handling here might be the handling of excrements. But the Jungian example is, as Twombly emphasizes, "based on the use of words, how you affect the child." What children have, is a sort of infantile thing (a certain relation to speech as well as to matter - as well as to hands). The child here, a girl, is making a sculpture because her answer refers to her father's question What are you making? What the child has is not what it makes. The child doesn't take possession of the sculpture, nor does it give it away as a gift, nor does it store it in view of a future exhibition, but the child has, without having it as its own, a sort of infantile thing. It responds to the question of making in a mimicking way. It makes up its answer. As if this child were imitating the Child (which, according to a certain tradition, incorporates the mimetic faculty par excellence). What the child is making here, behind closed doors, remains a certain secret. She answers Four horses and a carriage. Twombly continues, taking the word handling as an opportunity to draw attention to his (drawing) hands: "I start out using a brush but then I can't take the time because the idea doesn't correspond, it gets stuck when the brush goes out of paint in a certain length of time. So I have to go back and by then I might have lost the rest of it. So I take my hand and I do it. [Let me just emphasize the strange turn of phrase, take to the hand: I have to take my hand, but there is no hand to take it; I have to take, to consider taking in another way, without my hand, in ways that I am not used to, in order to take the time: to do something to time: to interrupt the drawing of its line, in order to draw in another way.] Or I have those wonderful things that came later: paintsticks. Because the pencil also breaks if the canvas is too rough. So I had to find things that I could use, like my hands or the paintsticks. [Again: dwell with this strange notion: I had to find things that I could use, like my hands: my hands were not given to me, they were not, they never are, at hand, in order to be taken; I had to find them and take them into consideration differently.] I can carry through the impetus till it stops. It's continual. I mean, I'm talking about specifics, the heavy kind. And also, when I talked about the Jungian thing ... I use earth things and certain human things as symbols for earth - like it might be excrement but it's earth." What the child is 
drawn to might be excrement, but it's earth. But what, a child might carry on to ask, is earth? And what about the sculpture it is making out of earth: four horses and a carriage?

The second version of that little story which Twombly borrows from Jung (but he obviously is drawn to it) takes a similar course. It starts with a selfcharacterization: "I'm a Mediterranean painter. I like that idea of a northerner in the Mediterranean, but more blood and guts...." The word Mediterranean here echoes the statement "like it might be excrement but it's earth": it situates the painter in the middle, in the midst of earth, in the heart of earth or in the earth as heart. In this version too, Twombly first refers to the Ferragosto paintings before inserting that little story: "I'm a Mediterranean painter. I like that idea of a northerner in the Mediterranean, but more blood and guts, like the Ferragosto, say. / Speaking of those paintings, there was a child in the bathroom and the father came to the door because she was there so long, and he said, 'What are you doing dear?' She said, 'I'm making four horses and a carriage.' In North Africa, the Arabs used their left hand to clean themselves. And so the paintings are a whole combination of that, and my revulsion for the viscousness of the paint, which entered into that wonderful series with the smears. But it didn't just come from my imagination or anything that I would be involved in, but from Jung and from being in North Africa, which I wouldn't have got if l'd stayed in Virginia.... That little story. It's about words, how you can affect the character of a child by using words. He used the word making, so she was constructing, but I guess that was only one version. And probably Expressionism to an extreme extent is what psychiatrists call anal rebellion, which is very easy if you get paint." If you are a psychiatrist the answer to the initial question What draws a child to paint? might be plain: Anal rebellion. But if you are a painter, the analyst's answer remains unsatisfactory, in a sense. That little story is made out of words, almost identical words in both versions retold by Twombly in two interviews. But the little story is also "about words, how you can affect the character of a child by using words." Twombly's insistence on the words of the story might invite to take a look at the third version, the one written or drawn by Jung. Its English 
translation can be found in Symbols of Transformation. An Analysis of the Prelude to a Case of Schizophrenia, published in 1956 from Symbole der Wandlung (Zurich 1952). In the chapter entitled "The Origin of the Hero" Jung introduces the anecdote with a general remark about children's interest in "the act of defecation and its products": "We can only begin to understand this interest when we realize that the young child connects defecation with a theory of propagation. This puts a somewhat different complexion on the matter. The child thinks: that is how things are produced, how they 'come out.'" And Jung continues: "The same child on whom I reported in my 'Psychic Conflicts in a Child' [where he gives the child a name: "the child, whom we will call Anna"] and who had a well-developed anal birth theory ... later contracted the habit of sitting for hours on the toilet (hat später eine gewisse Gewohnheit angenommen, längere Zeit auf dem Klosett zu verweilen). On one occasion her father, growing impatient, went to the toilet and called: 'Come out at once! Whatever are you doing?' ('Komm doch endlich mal raus; was machst du denn?') Whereupon the answer came from within: 'I'm doing a little cart and two ponies!' ('Ein Wägelchen und zwei Ponies!') So the child was 'making' a little cart and two ponies, things she particularly wanted at that moment. In this way one can make whatever one wishes." With words, one might add, no less than with paint (or excrement, or earth), you can make whatever you wish. What is striking at first sight, if you compare Jung's version of the story with Twombly's rendition, is the change in the child's answer, the change in words about what the child is making. In Jung, the answer from within the toilet states: I'm doing a little cart and two ponies! whereas in Twombly's two versions the answer is slightly but decidedly different: I'm making four horses and a carriage. How does this change of words, which refer to what the child is making or drawn to say it does, affect the painter's relation to what draws a child to paint? If you compare Jung's and Twombly's versions of the little story, there are several shifts at work. Twombly drops the word toilet, which is replaced by bathroom. Or, more precisely: he paints over the word toilet in order to withdraw the word from the surface of the story and keep it for some other, less conspicuous use. The same may be said of the substitution 
in the girl's answer. Twombly seems to want her to make something slightly different. Things he particularly wants (her to say she makes) in both the 2000 and 2007 interviews. Bridging a gap of seven years, Twombly insists on the shift in what he says she does. In this way, by replacing or painting over her answer in Jung's version - l'm doing a little cart and two ponies! - by another - I'm making four horses and a carriage -, one can indeed make whatever one wishes. But why should Twombly wish to draw two ponies and a little cart out of the toilet (including the word toilet), drawing four horses and a carriage into the bathroom instead? What is happening here is not simply a substitution but a kind of metonymical operation, contaminating what the painter is drawn to draw out of the toilet with what he is drawn to draw into the bathroom. One detail in Jung's version may illustrate how this contamination takes place. In his words the little girl "later contracted the habit of sitting for hours on the toilet." I emphasize the words for hours. Twombly might have drawn the expression four horses out of for hours; he might have teased four horses out of for hours. He might also have remembered the resonance of hours and horses with the word hero that appears in the title of this chapter in Jung's Symbols of Transformation: "The Origin of the Hero." What takes place here is less the transformation of a given archetype - that of the hero for instance - than a certain overdetermination, or fissuring, of what at first glance seems to be a given word or type. Both versions of the little scene or story, inserted into one another, produce, but only in what the painter does to the analyst's version, layer after layer, of traces (or paint), referring to, as well as interrupting, each other. He turns the prepositional indicator of an indistinct period of time - for - into a number - four -, leaving four at the surface of what the child is making. This number - four - resonates with at least two words in Jung's version, which Twombly paints over: with toilet and cart. If (unharnessing the horses for a moment) you relate the number, four, to the cart, you will find in cart, as if motivated by the numerical indicator four, an echo of quartet; four and quartet bound together form four quartets: not just any four quartets but those written by T.S. Eliot. 
In two canvases from his most recent series of rose paintings, five distinct sections of diptychs, triptychs and polyptychs, finished in 2009, Twombly inscribes lines from the first and last poems of Eliot's Four Quartets. The excerpt from the first of these quartets alludes to the door which only Twombly mentions in both variants of his version of Jung's little story: "The child is in the bathroom and the father gets very anxious. So he goes to the door and says...."; and: "there was a child in the bathroom and the father came to the door because she was there so long, and he said....." These are the lines drawing the reader towards the door in Eliot's first quartet (Burnt Norton): "Footfalls echo in the memory / Down the passage which we did not take / Towards the door we never opened / Into the rose-garden." This is where Twombly cuts, but Eliot continues (with two more lines that evoke how his words may have stayed with Twombly): "My words echo / Thus, in your mind."

At this point it is worth remembering another anecdote about Cy Twombly's early encounter with Jackson Pollock, whom Twombly apparently met on four different occasions in 1956. And at each of these occasions, according to Twombly, Pollock only asked him one question, four times the same: "And what is it that you do?" (Twombly in conversation with Nicholas Cullinan, Gaeta 29 June 2007; Robert Rauschenberg recalls much the same type of encounter during the early 1950s: "Pollock always opened every conversation with me by asking, 'Who are you? What do you do?'".) It is worth attending to this anecdote seriously, at least for a moment, for it places Pollock in the position of the anxious father and the young painter in that of Anna, the little girl behind the door. The unrecorded answer to Pollock's question seems to be hidden in the first of Eliot's Four Quartets: it turns the toilet, or the young artist's studio, into a rose-garden. What Twombly does is draw roses into earth, out of earth. Or, less forcefully: he sees the rose as something risen. If you elide four horses you are left with forces drawing out the rose: the emblem of those forces, themselves drawn out of earth, which make the rose rise: it is a force of literal transmutation drawing roses, heroes, horses, out of each other, into each other.... 
The third of Eliot's Four Quartets (The Dry Salvages) contains a passage that Twombly never painted. The poem apostrophizes the river as "a strong brown god": "I do not know much about gods; but I think that the river / Is a strong brown god - sullen, untamed and intractable, / Patient to some degree, at first recognized as a frontier; / Useful, untrustworthy, as a conveyer of commerce; / Then only a problem confronting the builder of bridges. / The problem once solved, the brown god is almost forgotten / By the dwellers in cities - ever, however, implacable, / Keeping his seasons and rages, destroyer, reminder / Of what men choose to forget. Unhonoured, unpropriated / By worshipers of the machine, but waiting, watching and waiting." In the second interview, with Nicholas Serota in 2007, Twombly states: "I've always wanted to do brown paintings, because when I was in school I realized in that great room at the Frick Collection in New York, with all those incredible paintings, that the secret to great paintings is brown. And that is one of my great ambitions, to strive to do a brown painting."

The second excerpt that Twombly inscribes in one of the five panels of his latest series of rose-paintings are these lines at the end of the fourth quartet (Little Gidding): "And all shall be well and / All manner of things shall be well / When the tongues of flames are in-folded / Into the crowned knot of fire / And the fire and the rose are one." These lines, which end the last of Eliot's Four Quartets, have a Pentecostal shape. And so has the rose. This rose, the Pentecostal rose (or Pfingstrose in German), bears a name in English that stems from the Greek - paionia - and the botanical Latin - Paeonia - to give peony. In late Fall and early Winter 2006/2007, immediately before he starts painting the five panels of The Rose, to which I will turn shortly, Twombly paints a series of six so called Peony Blossom Paintings, which he finally titles Blooming: $A$ Scattering of Blossoms and Other Things. One of these Other Things is scattered in the blooming peony. This Pentecostal rose, or word - peony - catches on fire, if one may say so, under Twombly's tongue or hands. It echoes the pony and ponies in Jung's version of that little story. "I don't know," says Twombly in the 
2007 interview with Nicholas Serota, "what excited me with the Blossoms." That is with the peonies. It might have been two ponies remembered from Jung.

What draws a child to paint? What the child is drawn to drawing, to modeling or to making, in the case of that little story, are two ponies or four horses; they draw a cart, a carriage. What draws, in Twombly's version, is a horse, or more precisely, are four horses, condensed (and intensified) into forces. The drawing force. In his essay The Practical Use of Dream-Analysis (from 1934, English translation 1954) Jung, analyzing two dreams of a seventeen-year-old girl with "the two main symbols, 'mother' and 'horse,"' draws a couple of lines between what he calls these two archetypes: "'Mother' is an archetype and refers to the place of origin, to nature, to that which passively creates, hence to substance and matter, to materiality, the womb, the vegetative functions. It also means the unconscious, our natural and instinctive life, the physiological realm, the body in which we dwell or are contained; for the 'mother' is also the matrix, the hollow form, the vessel that carries and nourishes, and it thus stands psychologically for the foundations of consciousness. Being inside or contained in something also suggests darkness, something nocturnal and fearful, hemming one in." Jung is filling the cave, a womb- or tomb-like hollow, with what mother might mean, allude or refer to. But referring to the archetype in this case is referring to what undoes reference. The mother doesn't carry, does not refer to the original meaning of this or any other archetype. The semantically satisfying filling of mother remains wishful thinking because, as Jung emphasizes, "the underlying, primary psychic reality is so inconceivably complex that it can be grasped only at the farthest reach of intuition, and then but very dimly." Horse, another archetype, doesn't carry any farther. It runs wild. To quote Jung: "'Horse' is an archetype that is widely current in mythology and folklore. As an animal it represents the non-human psyche, the subhuman, animal side, the unconscious.... As an animal lower than man it represents the lower part of the body and the animal impulses that rise from there. The horse is dynamic and vehicular power: it carries one away like a surge of instinct." And Jung concludes: "It is evident, then, that 'horse' is an equivalent of 'mother' with a slight shift of 
meaning. The mother stands for life at its origin, the horse for the merely animal life of the body." What the mother, forcefully, brings to the fore, is not just a horse; what she helps to be drawn out of her womb is oscillating between something simply drawn and something drawn to draw in its turn some other thing: between a cart and two ponies drawing and a cart; a carriage and four horses drawing a carriage. If you try to apply this slightly shifting set of meanings, which doesn't form a matrix or a pattern, between horse and mother to that little story, then the little girl is mimicking the mother as that which "stands for life at its origin." She doesn't simply do as if she gave birth to four horses (that is to her mother or to mother's force, drawing a carriage: a girl into life), but she is drawn to drawing what one might call the scene of birth, of making or doing: poiein. A scene, which doesn't allow to draw a strict line between painting, sculpting and drawing. Her answer to the anxious father's question What are you making? might have been: I am making - mimicking - the (scene of) origin of making: force draws a carriage drawn by four horses. I gave rise to what draws, I gave rise to what rose. But the relation between what draws and what is drawn (to draw) remains open. Four-horses-and-a-carriage foreclose a strict distinction between what draws and what is drawn (to draw). Like the rose. The rose condenses the phrase four horses and a carriage. (At the origin of drawing there is no drawing of its origin.)

Allow me to insert one more detour on our way to Twombly's roses, which might help to specify the status of the place of origin of making in Twombly's reading of that little story. The detour leads through some passages of a book that Twombly highly appreciates: Etruscan Places by D. H. Lawrence, published in 1932. These Etruscan places, almost exclusively, are tombs. The painted tombs of Tarquina. (In an undated letter to Leslie Check, Jr., probably written in May 1953, Twombly writes: "I was quite taken by the Etruscan's civilization, and made many trips to the tombs of Tarquinia and Volci".) The first surprise, in Lawrence's description of the path to these painted places or painter's places, comes in seeing "the phallic stones by the doors of many tombs.... The big phallic stones that, it is said, probably stood on top of the tumuli, are sometimes 
carved very beautifully, sometimes with inscriptions." The tombs themselves impress Lawrence as womblike: "The stone house, as the boy [accompanying the writer as a guide] calls it, suggests Noah's Ark without the boat part: the Noah's Ark box we had as children, full of animals. And that is what it is, the Ark, the arx, the womb. The womb of all the world, that brought forth all creatures. The womb, the arx, where life retreats in the last refuge. The womb, the ark of the covenant, in which lies the mystery of eternal life, the manna and the mysteries.... The Etruscan consciousness was rooted quite blithely in these symbols, the phallus and the arx." The inner walls of these womb-like tombs are all painted. This is the description of the last tomb that Lawrence visits on the first day: "We decide that the Tomba delle Iscrizioni, the Tomb of the Inscriptions, shall be our last for to-day. It is dim but fascinating, as the lamp flares up, and we see in front of us the end wall, painted with a false door studded with pale studs, as if it led to another chamber beyond; and riding from the left, a trail of shadowy tall horsemen; and running in from the right, a train of wild shadowy dancers wild as demons. / The horsemen are naked on the four naked horses, and they make gestures as they come towards the painted door. The horses are alternately red and black, the red having blue manes and hoofs, the black, red ones or white. They are tall archaic horses on slim legs, with necks arched like a curved knife. And they come pinking daintily and superbly along, with their long tails, towards the dark red death-door. [This chamber, if you link the description of the paintings covering its walls to Twombly's version of that little story, is an echo-chamber: it suggests that Anna, hidden behind the bathroom door for hours, drawn to make fourhorsesandacarriage, rose the dead. T. S. Eliot's rose garden is a churchyard covered in roses: with those who rose from underneath the earth, within roses.] / From the right, the stream of dancers leaps wildly, playing music, carrying garlands or wine-jugs, lifting their arms like revelers, lifting their live knees, and signaling with their long hands. Some have little inscriptions written near them: their names." The description of these painted subterranean Etruscan places features evocations of men painting themselves "in the early days" (you may notice that a certain Jungian terminology insinuates itself in the description): "In 
the early days men smeared themselves with scarlet when they took on their sacred natures. When they wish to figure in their sacred and portentous selves they smear their bodies all over with red.... It is a very old custom.... It is deeper even than magic. Vermilion is the colour of his sacred or potent or god body. Apparently it was so in all the ancient world. Man all scarlet was his bodily godly self.... That is the treasure. The active religious idea was that man, by vivid attention and subtlety and exerting all his strength, could draw more life into himself, more life, more and more glistening vitality, till he became shining like the morning, blazing like a god. When he was all himself he painted himself vermilion like the throat of dawn, and was god's body, visibly, red and utterly vivid.... There were only idols or symbols. It was the living cosmos itself, dazzling and gaspingly complex, which was divine, and which could be contemplated only by the strongest soul, and only at moments. And only the peerless soul could draw into itself some last flame from the quick. Then you had a king-god indeed. / There you have the ancient idea of kings, kings who are gods by vividness, because they have gathered into themselves core after core of vital potency from the universe, till they are clothed in scarlet, they are bodily a piece of the deepest fire." This is the place to recall the last lines from Eliot's last Quartet, which Twombly inscribes into one of the canvases of his latest series of rose-paintings: "Quick now, here, now, always — / A condition of complete simplicity / (Costing not less than everything) / And all shall be well and / All manner of thing shall be well / When the tongues of flame are in-folded / Into the crowned knot of fire / And the fire and the rose are one." This time, in this context, the rose finds itself poised between scarlet and vermilion, affecting both: turning the smeared and painted bodies into blooming flowers. In the early days, as Lawrence indicates, it was the treasure of men and women, to draw: to draw "more life into himself, more life, more and more glistening vitality," until man was drawn to paint, him- or herself: "When he was all himself he painted himself vermilion." What man is drawing in here is not something the gesture of drawing helps to inhale, but the experience of drawing in: of breathing in - and breathing out: the quintessence of feeling alive; in other words: to burn. The same treasure or secret of drawing 
affects the soul. The soul draws into itself the very experience of drawing in, until the soul itself is drawn to paint - the body: "only the peerless soul could draw into itself some last flame from the quick," until the body was "clothed in scarlet." This is the treasure: to draw until (being) clothed in (scarlet, vermilion, red) paint, where "the fire and the rose are one." But beyond the indicated treasure or secret, there is, according to Lawrence, a treasure of treasures: "The treasure of treasures is the soul, which, in every creature, in every tree or pool, means the mysterious conscious point of balance or equilibrium between the two halves of the duality, the fiery and the watery. This mysterious point clothes itself in vividness after vividness from the right hand, and vividness after vividness from the left." The mysterious character of the soul, the clothing of this point - of paint -, the augmentation of countless layers or veils of vividness, depends on both: on the right as well as on the left hand. This passage, in Etruscan Places, echoes Aristotle's likening of the soul to the hand in his treatise On the Soul, where it is said: "The soul, then, is like the hand [hoste he psuche hosper he cheir estin]; for the hand is the instrument of instruments [kai gar he cheir organon estin organon]" (III, 432a). Aristotle's notion of the hand as the instrument of instruments, which echoes in Lawrence's calling the soul the treasure of treasures, tries to grip the hand, to get a hold on both hands by getting rid of the difference between right and left and turning the hand's quintessence, the handiness of the hand, into a gesture of grasping, catching, or holding. But as much as a hand may grasp and hold it may loosen the grip and even lose interest in grasping, remaining itself without hold, open and ungraspable: lost or useless for any instrumental need. Ungraspability - be it that of the hand, considered by Aristotle as the instrument of instruments, or of the soul, considered by Lawrence as the treasure of treasures - affects the instrumental and gratifying character of everything. Ungraspability of the hand, the instrument par excellence of grasping, not only causes oscillation between usefulness and uselessness, value and worthlessness in general, but exposes the uselessness and worthlessness of such distinctions. Emphasizing the soul's dependence on both hands, as different from each other, Lawrence runs the risk or takes 
pleasure in a sense at losing the drawing hand's destination as well as the destination of painting in general. His introduction of both hands into the soul is emphasizing this: the point of paint (between two hands) is that it has no destination. What draws a child to paint is the pleasure to lose destiny and destination. Twombly will take to heart this pleasure and this loss. Late in autumn of 1953, having been drafted into the U.S. army, "Twombly ... attends cryptography courses at Camp Gordon, near Augusta, Georgia. At weekends, he rents a hotel room in Augusta, drawing there at night with the lights out, to lose," as Nicholas Cullinan writes, "the habits he has acquired with his academic training and to distort his graphic skills," or, in Kirk Varnedoe's words, "to force into [the drawing hand] some of the distortions of children's drawings." Drawing blindly in the night, Twombly forces the right hand, the brush-holding hand, to get in touch with the left, a child's hand, as if drawn by this child to paint, with both hands. Painting with both hands does not extend the fluency or the virtuosity of the drawing hand from the right to the left, but introduces within the act of doing the undoing of this very act; it introduces into the paint as ergon traces of aergonality; and into the act of creation - traces of decreation. The point or place between these tendencies, where, as Twombly writes in 1957, "I break with the more general processes of painting," is the place where tomb and womb intersect, but neither in the name of the one or the other. Lawrence's Etruscan Places already allude to this inscription of tomb and womb, into one another: "In the tombs we see it; throes of wonder and vivid feeling throbbing over death. Man moves naked and glowing through the universe. Then comes death: he dives into the sea, he departs into the underworld. / The sea is that vast primordial creature that has a soul also, whose inwardness is womb of all things, out of which all things emerged, and into which they are devoured back." Lawrence's description of the relation between tomb and womb is chiastic. The tomb is a place in the throes of a coming birth; while the womb is like a grave, into which all things are drawn back. The same chiasmus is at work in the relation that Lawrence describes between children and adults as it was in ancient times and today: "The ancients were like children: but they had the force, the 
power and the sensual knowledge of true adults. They had a world of valuable knowledge, which is utterly lost to us. Where they were true adults, we are children; and vice versa." Divorced from both adulthood and childhood, the painter's place is neither tomb nor womb, but twomb.

The Etruscan Places are painted tombs. It is looking at these paintings, with a child's eyes, that undoes the feeling for the line of demarcation between life and death, tomb and womb. But how is one to catch sight of a painted horse, of what Lawrence figured as the allegorical quintessence of the painter's force? How does one get hold of a painter's force in looking at a painted horse? The second day, inside another tomb, Lawrence raises precisely this question: "Another very fine tomb is the Tomb of the Baron.... There are horses and men, all in dark silhouette, and very fascinating in drawing. These archaic horses are so perfectly satisfying as horses ... so that one asks oneself, what, after all, is the horsiness of a horse? What is it that man sees, when he looks at a horse? - what is it, that will never be put into words?" Still further down, Lawrence puts into words (words that could have been taken from Jung), what will never be put into words: "The horse is always the symbol of the strong animal life of man: and sometimes he rises, a sea-horse, from the ocean: and sometimes he is a land creature, and half-man. And so he occurs on the tombs, as the passion in man returning into the sea, the soul retreating into the death-world at the depths of the waters: or sometimes he is a centaur, sometimes a female centaur, sometimes clothed in a lion-skin, to show his dread aspect, bearing the soul back, away, off into the otherworld." The horse is the symbol of a force that hinders human beings from taking leave from sheer animal life. It rises, it rose from inside, turning them into male and female centaurs, drawing the soul back to as well as back from the world of the living and the world of the dead, without belonging to either one or the other, the dead or the living. What from within all these words, turned into each other, - horse - force - centaurs - and others -, rose, the slightly shifting, slightly fissured verb, imperceptibly saying the horse's force or force as a horse, is The Rose. The Rose is, as you can see (with a child's eyes), 
or hear (opening a child's ear) -; the Rose is not The Rose, but like a turmoil of gestures drawn to paint the (silent) heart of a cyclone (or Cy).

The Rose is a cycle of five paintings, numbered $I-V$, variations of each other, without showing a theme or paradigm. At the upper right side, each painting is signed $C T$, and indicates the place and date of their fabrication in red (or scarlet) color: Gaeta, $11-08$. The cycle was exhibited for the first time at the Gagosian Gallery in London, between February 12 and May 9, 2009. Each canvas $(252$ by $740 \mathrm{~cm})$ repeats a certain scheme, with slight deviations.

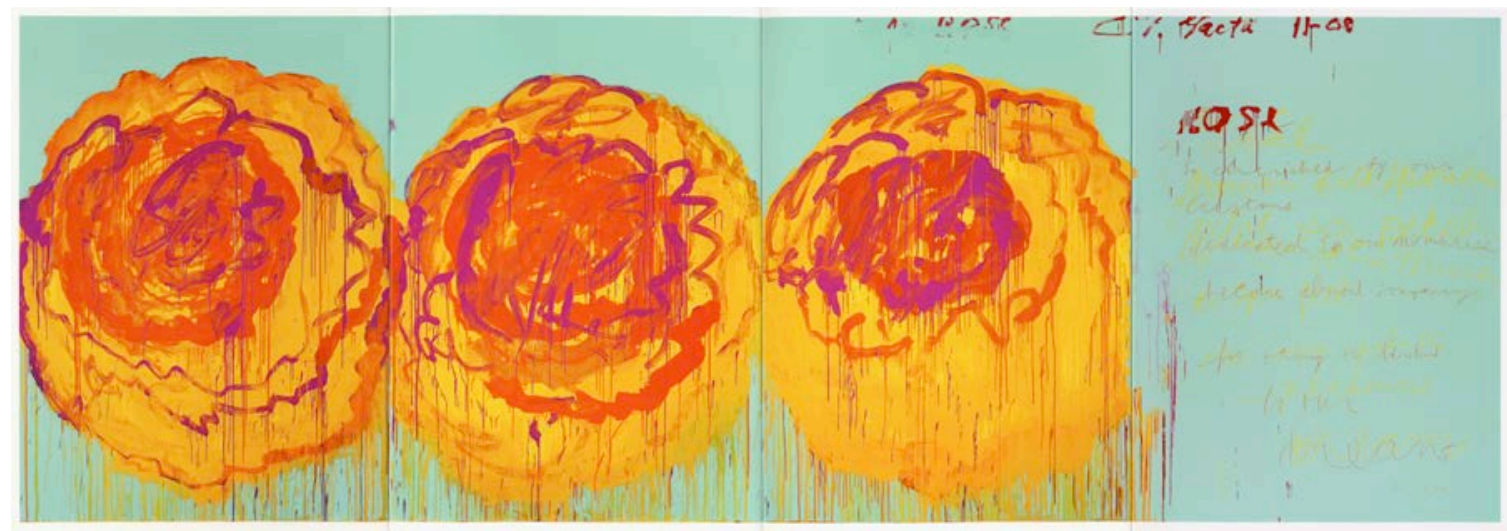

Figure 1. Cy Twombly, The Rose (I), 2008, Acrylic on plywood, $252 \times 740 \mathrm{~cm}$. (Exhibited at the Gogosian Gallery 2009).

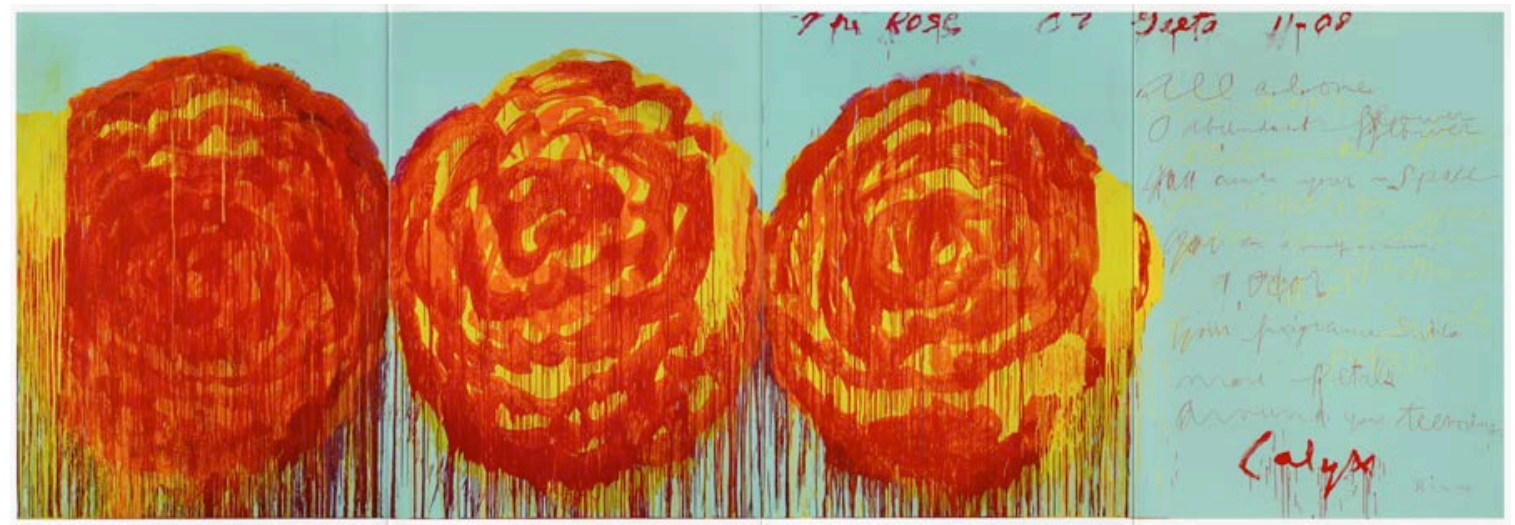

Figure 2. Cy Twombly, The Rose (II), 2008, Acrylic on plywood, $252 \times 740 \mathrm{~cm}$. (Exhibited at the Gogosian Gallery 2009). 


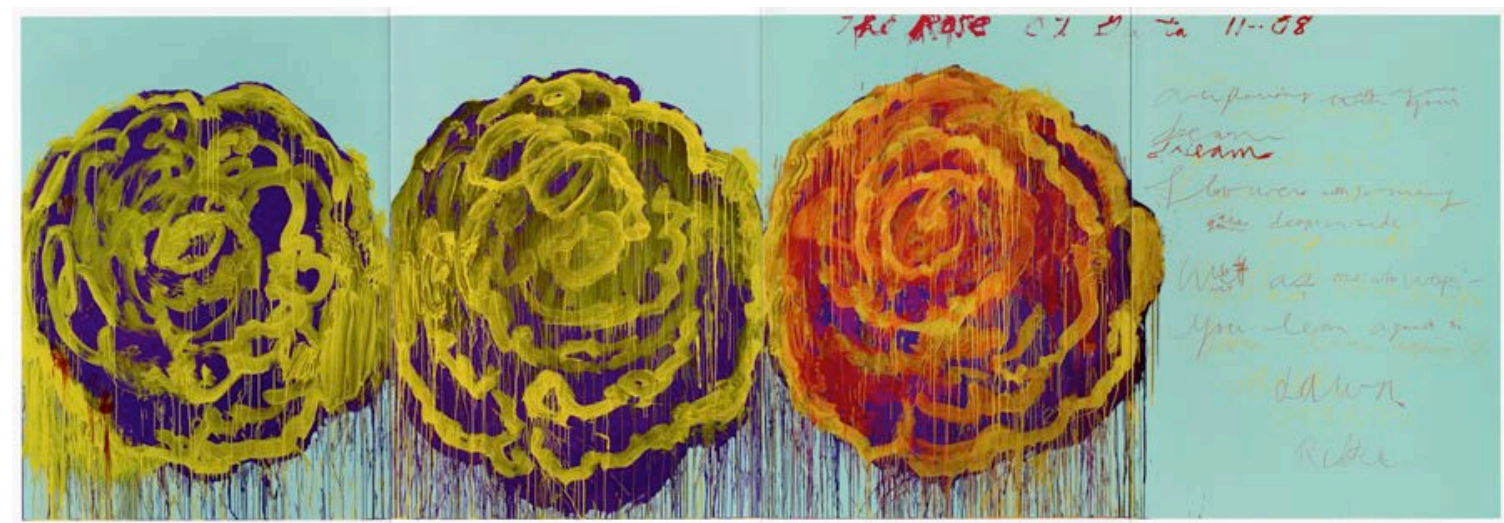

Figure 3. Cy Twombly, The Rose (III), 2008, Acrylic on plywood, $252 \times 740 \mathrm{~cm}$. (Exhibited at the Gogosian Gallery 2009).

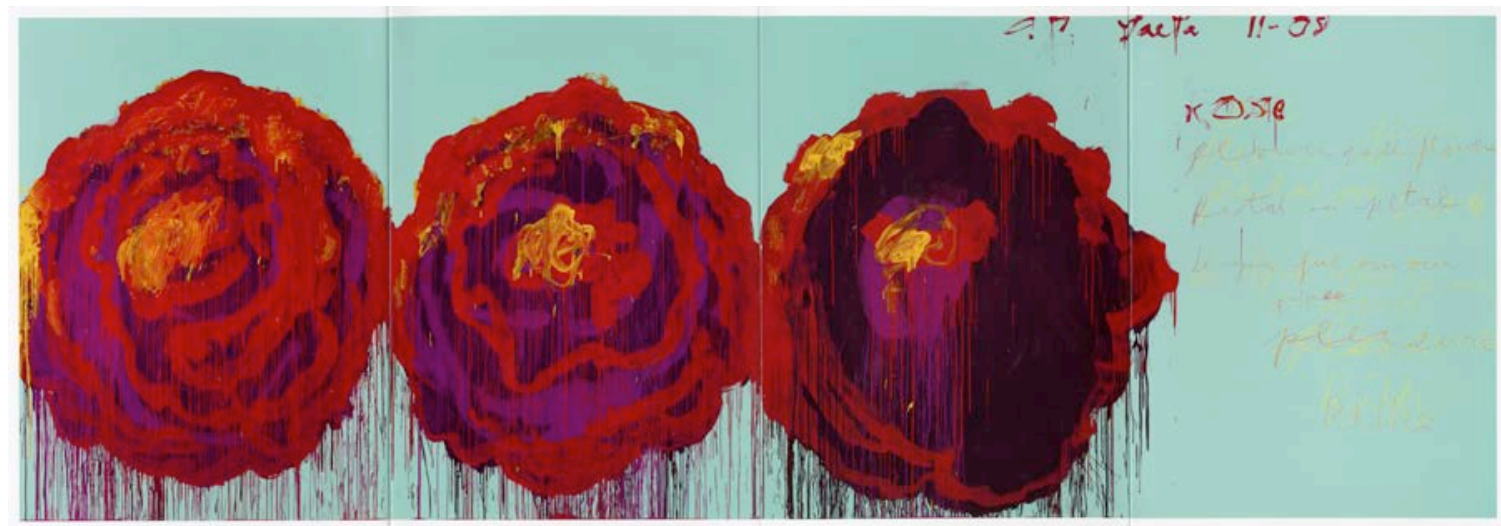

Figure 4. Cy Twombly, The Rose (IV), 2008, Acrylic on plywood, $252 \times 740 \mathrm{~cm}$. (Exhibited at the Gogosian Gallery 2009).

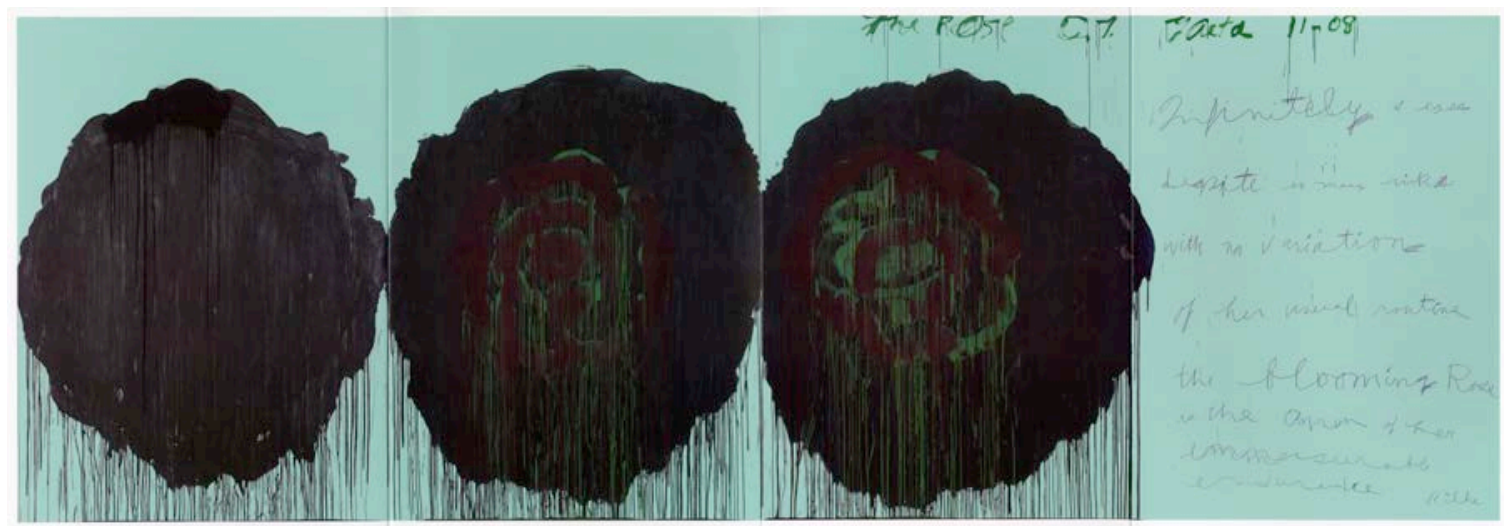

Figure 5. Cy Twombly, The Rose (V), 2008, Acrylic on plywood, $252 \times 740 \mathrm{~cm}$. (Exhibited at the Gogosian Gallery 2009).

If you consider each canvas as a fourfold painting, or quartet, you can see, from left to right, something like three blooming roses or three variations drawn out of 
a first or fourth, The Rose, followed by or following, or drawn by, excerpts from the English translation, by A. Poulin, Jr., from several poems of a cycle of 27 poems, written in French by Rainer Maria Rilke, between 1922 and 1926, and entitled Les roses. Of particular interest in Twombly's composition of The Rose is the status of the text inscribed into the fourth or first part of each of these five quartets. Every text, at the bottom, is signed by the name Rilke. But this signature is a palimpsest. Twombly is not copying words from Rilke's French original, but fragments from Poulin's English translation. The signature Rilke is hiding or covering another: Poulin, not only the translator's name, but also a French noun. Poulin is a variation (known for instance to Buffon) of the French noun poulain, designating, according to Emile Littré, le "nom du cheval avant l'âge adulte," a young horse. Littré draws the word's etymology from Latin pullus, a contraction of puellus, the diminutive of puer: infant, child. But there is more to be drawn from poulin. A German Etymological Dictionary, under the lemma Pony, deduces the English noun, via Scottish pown(e)y, from Middle French poulenet, diminutive of poulin. The translator's name, Poulin Junior, draws the silhouette of a young pony. Looking back to that little story, found in Jung, and mentioned by Twombly in both interviews, from 2000 and 2007, the father's question, What are you making? allows the following answer, when considering the 5 quartets of The Rose: $A$ (young) pony and three roses. Situated the intersection of Jung's $A$ little cart and two ponies and Twombly's Four horses and a carriage. The Rose as the title of the five quartets can be read as a fragmentary palimpsest or rest of some other title: $A$ (young) pony and three roses. [Or: A portrait of the artist as a young pony (and three roses)]. Among countless other titles. The lines inscribed into the right section of each of the five quartets, drawn from the English translation by Poulin of Rilke's French cycle of poems entitled Les roses, are sketching, almost invisibly, a figure oscillating between a young horse and a young pony, or even less: fissured fragments of a colored headgear out of use: scattered remainders of a child's silhouette drawn to paint. 
Instead of beginning to read, with a child's eyes, these five quartets in detail, an infinite task, l'd like to draw your attention, and in order to conclude this talk, to one single detail among countless others. The detail in question is to be found on two of the five canvases, $I$ and $I V$. Both are situated at the far right side of the fourfold painting. They have to do with Twombly's transcriptions of Poulin's English translations. On canvas / Twombly inscribes fragments from stanza 1 of Rilke's poem number 24, followed by fragments from stanza 1 of poem number 25. On canvas $I V$, Twombly repeats, but this time without adding fragments from another poem, the same fragments from stanza 1 of Rilke's poem number 24. Twombly's transcriptions never follow Poulin word by word. They all cut out entire lines or bits of lines. In the case of stanza 1 from Rilke's poem number 24 Twombly cuts out the same bits on both canvases. The four lines, that form the first quatrain, or stanza 1 in Rilke's French read as follows:

Rose, terrestre pourtant, à nous autres égale, fleur de toutes nos fleurs est-ce que tu sens en toi, pétale contre pétale, nos palpables bonheurs.

In Poulin's translation:

Rose, certainly earthly and our equal, flower of all our flowers, inside yourself, petal over petal, do you feel our own palpable pleasures?

Twombly's discussion of Poulin's quartet leaves Rose alone in line one, cutting out certainly earthly and our equal; it cuts out the pronoun our in line 2; and at the beginning of line 3 omits inside yourself. What remains after Twombly's almost surgical intervention, suspending any trace of equivalence and familiarity between the rose and us as well as between the rose and the rose itself, is the following, more sober version:

Rose

flower of all flowers 
petal over petal, do you feel

our own palpable pleasures

These remainders of stanza 1 are written in yellow crayon and superscribed, in yellow and red, with fragments from stanza 1 of Rilke's poem 25.

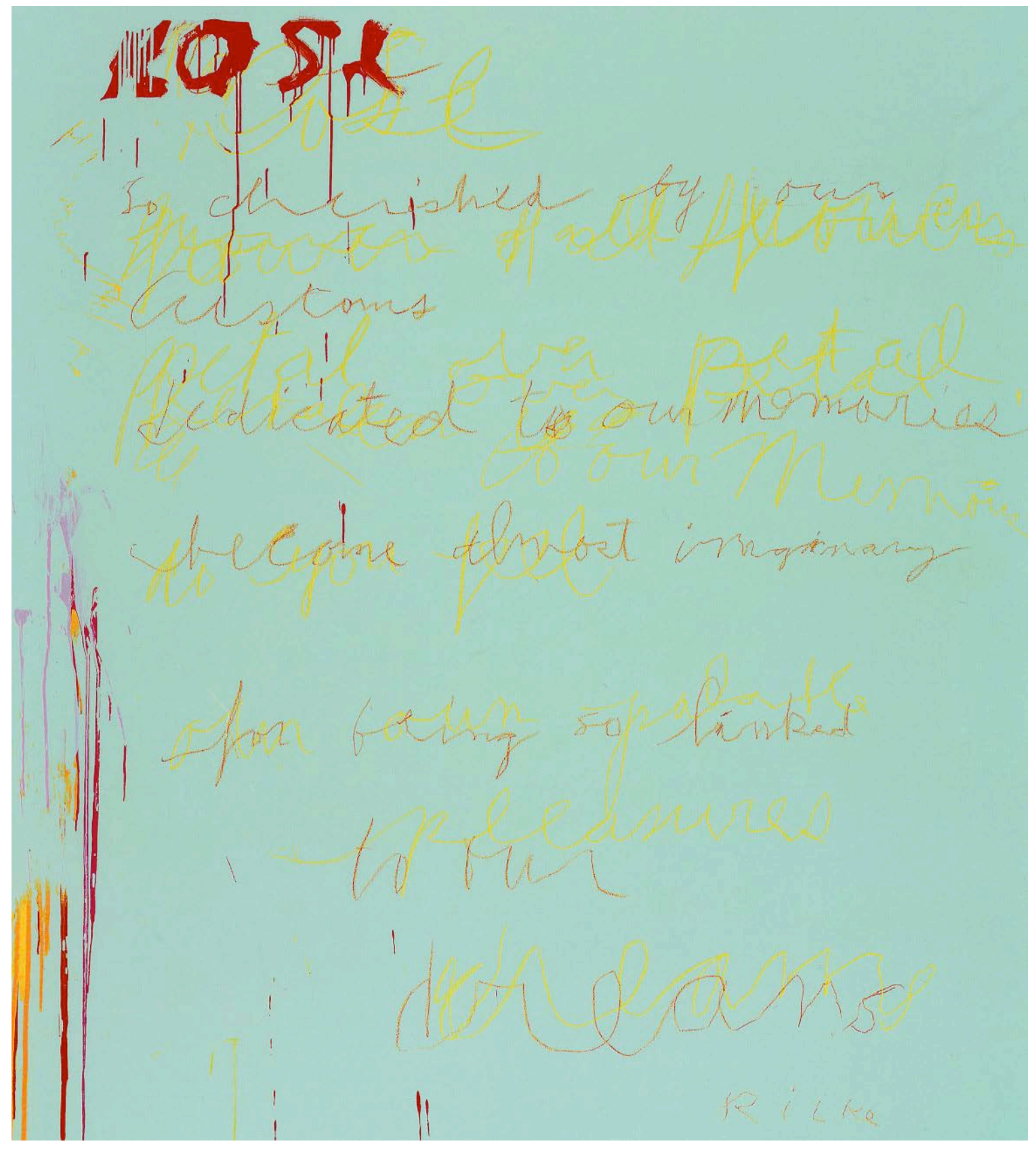

Figure 6. The Rose (I), detail 1 
A further deviation from Poulin's English version consists in repeating or repainting certain words and fragments of lines several times. At the top you can read Rose, scribbled three or four times; further down petal over petal is written over petal over petal. All these words inscribed in Twombly's childlike hand can be identified as words with the exception of one. It is the word palpable, spelled out as palable.

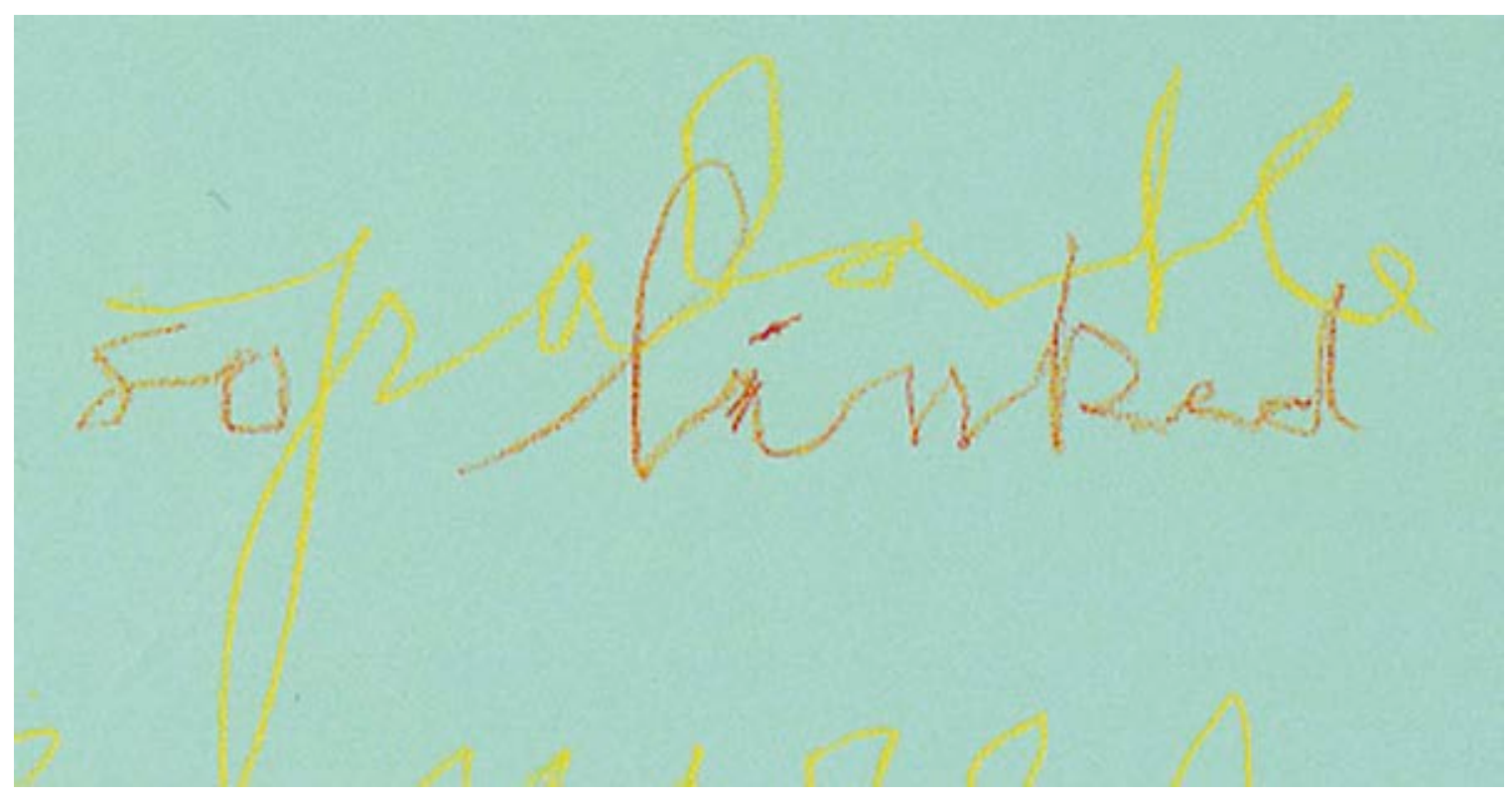

Figure 7. The Rose (I), detail 2

But this word is not just one among others. It designates the feeling as palpation and our palpating feeling as pleasure, which asks the rose whether it feels that we are able to feel (that we are feeling), or not. At stake here is nothing less than the question whether we are alive or not. According to a very famous and irritating passage in Aristotle's Nicomachian Ethics, the question of being alive is linked to the feeling of feeling: to feel that I feel. If it is the case, states Aristotle in book 9 of Nicomachian Ethics, that we feel that we are feeling [hoste aisthanoimeth' an hoti aisthanómetha (1170a)], then we are alive. The fact or facticity of life (zoe) depends on (squared) aisthesis (mise en abîme). The hand here - the hand being considered as the emblem of palp, palpation and palpability - does not reproduce a given word. It palpitatingly palpates the word 
palpable, leaving the word undone. The pleasure of this hand seems to consist but there is no consistency at play here - in suspending the desire to designate the gesture of the drawing hand by the word palpable; it suspends the belief in both faculties: the palpability of the hand as well as of the word. The hand undoes the word called upon to say what the hand is doing here. The drawing hand here is not drawn to draw in order to feel that it feels. It doesn't care whether it is alive or dead, whether being or not, whether what remains will remain for the living or the dead.

This inhibition, or pleasure, to spell out the word palpable differently, oscillating between doing and undoing, is intensified on canvas $I V$ :

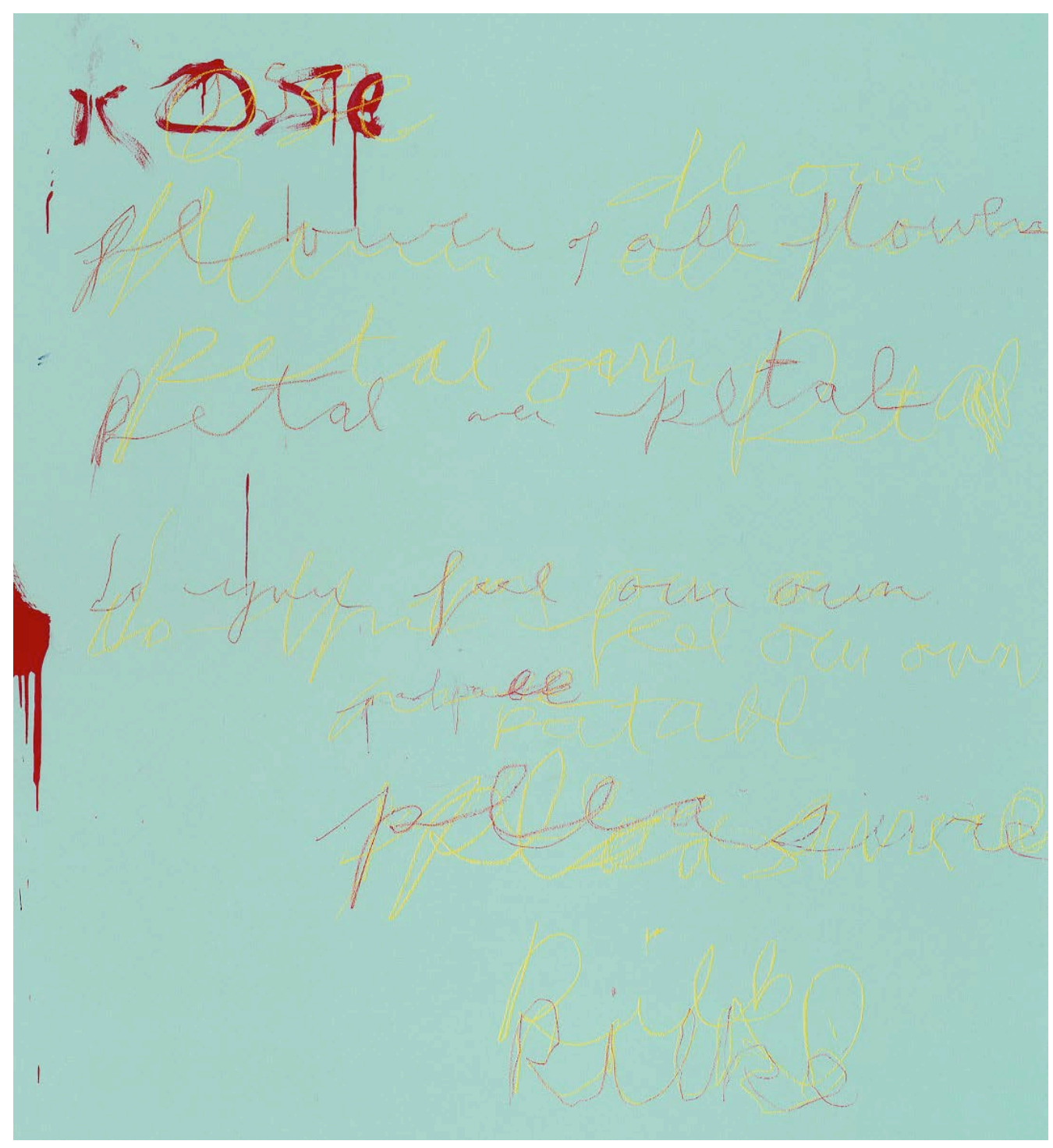

Figure 8. The Rose (IV), detail 1 
the reading, palpating eyes are erring between yellow traces, which they remain incapable to identify as letters of a given word, following traces of a scarlet word oscillating between palpabee palpable and palpale, and the yellow word or bit of word patabl.

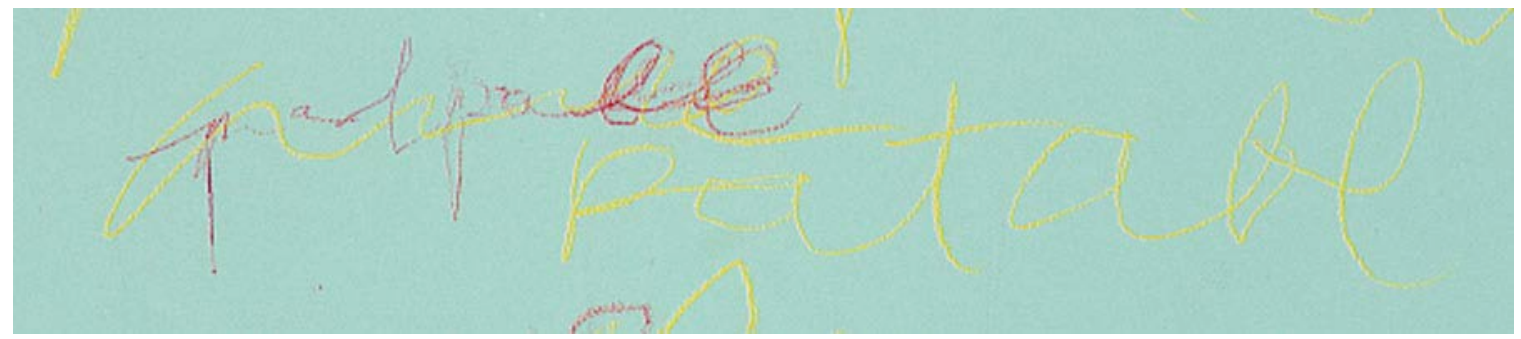

Figure 9. The Rose (IV), detail 2

What draws a child to paint? And I repeat: what was it that rose (where a child was drawn to paint)? Leaving you with the answer, that rose, almost impalpable, alone.

Works Cited

Cullinan, Nicholas, "American-Type Painting?" Twombly, Cy. Cycles and Seasons. London: Tate Publishing, 2008. 55-59. Print.

Eliot, T.S. Four Quartets. London: Faber and Faber [1944], 1959. Print. Etymologisches Wörterbuch des Deutschen. Ed.Wolfgang Pfeifer. München:

Deutscher Taschenbuch Verlag, 1995. Print.

Jung, C.G. Symbols of Transformation. An Analysis of the Prelude to a Case of

Schizophrenia [Symbole der Wandlung. Zürich: Rascher Verlag, 1952].

Trans. R.F.C. Hull. Princeton: Princeton University Press, 1967 [1956].190. Print.

Jung, C.G. "Psychic Conflicts in a Child." The Development of Personality.Trans. R.F.C. Hull. New York: Pantheon Books, 1954. 9. Print. 
Jung, C.G. "The Practical Use of Dream-Analysis." The Practice of Psychotherapy. Trans. R.F.C. Hull. New York: Pantheon Books, 1954. 158-161. Print.

Lawrence, D.H. Etruscan Places [1932]. New York: The Viking Press, 1963. Print.

Littré, Émile. Dictionnaire de la langue française [1876]. Vol. 6. Paris: Gallimard/Hachette, 1965. Print.

Rilke, Rainer Maria. Les Roses. Sämtliche Werke. Vol. 4. Frankfurt am Main: Insel Verlag, 1957. 535-584. Print.

Rilke, Rainer Maria. The Roses \& The Windows. Trans. A. Poulin, Jr. Port Townsend: Graywolf Press, 1979. Print.

Sylvester, David. Interviews with American Artists. New Haven and London: Yale University Press, 2001. 173-181. Print.

Twombly, Cy. An undated letter to Leslie Cheek, Jr. (probably written in May 1953). Qutd. in Varnedoe, Kirk. "Inscriptions In Arcadia." Cy Twombly. A Retrospective. The Museum of Modern Art, New York: Harry N. Abrams, 1994. 57-58. Print.

Twombly, Cy. Blooming. A Scattering of Blossoms and Other Things. Paris: Éditions Gallinard, 2007. Print.

Twombly, Cy and Serota, Nicholas. "History Behind the Thought." Twombly, Cy. Cycles and Seasons. London: Tate Publishing, 2008. 43-53. Print.

Twombly, Cy. The Rose. London: Gagosian Gallery. 2009. Print. Varnedoe, Kirk. "Inscriptions In Arcadia." Cy Twombly. A Retrospective. The Museum of Modern Art, New York: Harry N. Abrams, 1994. 9-64. Print. 